\title{
海水移行わよびシナホリン投与による養殖ウナギの 雄の腺性下垂体の形態変化
}

\author{
山本喜一郎* ・長 浜 嘉 孝** \\ (1972 年 11 月 4 日受理)
}

\begin{abstract}
Cytological changes in the adenohypophysis of fresh-water cultivated male Japanese eels, Anguilla japonica, induced to maturation by transfer to sea water and Synahorin injection
\end{abstract}

Kiichiro Yamamoto* and Yoshitaka Nagahama**

In the adenohypophysis of cultivated male Japanese eels, eight cell types (prolactin-, ACTH-, TSH-, STH- and GTH-cells in addition to two kinds of meta-adenohypophysial cells and chromophobic cells) were identified by both light- and electron-microscope.

In fresh-water fish, prolactin cells which occupy the major part of the pre-adenohypophysis and are arranged in the form of follicles, contain many secretory granules and highly developed rough endoplasmic reticulum and Golgi systems. STH cells occupy the major part of the meso-adenohypophysis and are strongly stained by azocarmine G. GTH cells are small in size and number, and are slightly stained by aniline blue and aldehyde fuchsin.

After transfer to sea water, prolactin cells became reduced in size, and the staining affinity and cellular organelles were regressed. TSH cells increased in staining affinity and its secretory granules became enlarged. A third meta-adenohypophysial cell was also encountered.

On the other hand, in the pituitary of the sea water eel induced to maturation by Synahorin injection, the meso-adenohypophysis became very enlarged. GTH cells increased in size, number and staining affinity for basic dyes. Ultrastructurally, two kinds of secretory granules, i.e. electron-dense smaller granules and less electron-dense larger granules were found. On the contrary, STH cells which were active in immature fish, were regressed.

OLIVEREAU らは種々の条件下にあるヨーロッパ産ウナギの脳下垂体について多くの形態学的研究を行なっ ているが ${ }^{1,2)}$ ，日本産ウナギ (Anguilla japonica) の媨下垂体の形熊学的研究は本間)の一般形態についての報

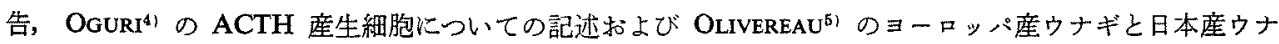
ギの比較についての簢単な記載があるのみで，全般的に脸下垂体の個々のホルモン産生細胞について詳細に 記述した報告は見当らない。著者の一人は先に日本座着殖ウナギの雄を海水移行と同時にシナホリンを投与 することにより排精に導くことに成功しだの。著者らは今回その際における脳下垂体を光顕捛よび電顕によ り観察し、各種ホルモン産生細胞の細胞学的特徵を明らかにし得たのでその結果を報告する。

稿を進めるにあたり，実験中種々の援助をたまわつた，北海道さけます孵化場の広井修氏，扣よび北海道大 学院生森岡孝朗氏に樑く感暗の意を表する。

\section{材料および方法}

本実験に用いた材料および海水移行，シナホリン投与の方法は前報们詳しく記したのでここでは省略し，

* 北海道大学水産学部 (Fac. Fish. Hokkaido Univ. Hakodate, Japan)

** Dept. of Zoology, Univ. of California, Berkely, U.S.A. 
細胞学的観察に用いた方法のみについて記述する。

奶照招よび実駼群のウナギをMS 222 で麻酔した後，断頭し脳下垂体をすばやく取出した。採集した脳 下垂体は光䫓観察のために BOUIN 液, ZENKER-formal 液, SUSA 液で固定し “Tissuemat”に包埋し，5$7 \mu$ の切片とし, HeIDENHAIN の azan 染色, MACCONALIL" の鉛へマトキシリン染色, HaLMI の aldehyde fuchsin (A-F) 染色などを施した後，観察した。さらに䉓子顕微鏡の観察のためには脳下垂体を前，中，後 腺性下垂体に分け各々を小片として MILLONIG 氏液で 2-4 時間固定し，通常法に従つてニポキシ樹脂に包

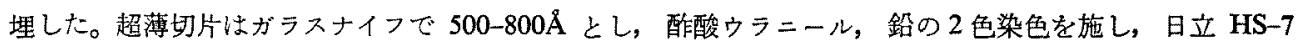
型電子顕變鏡で観察した。さらにエポン包埋したものの $1 \mu$ 切片を作成し, RICHARDSON ら し，超薄切片との比較に供した。

\section{結果}

日本産夌殖雄ウナギの脳下垂体の一般形態＼cjkstart正中線に沿つて切られた切片では養殖雄ウナギの脳下垂体

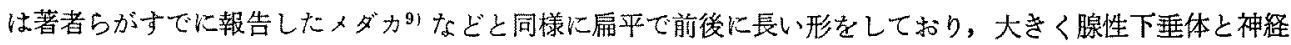
性下垂体に分けられる。前者はさらに前方部分上り前腺性下垂体，中腺性下垂体，後腺性下垂体の 3 部分に 分け於るとができる (Fig. 1)。

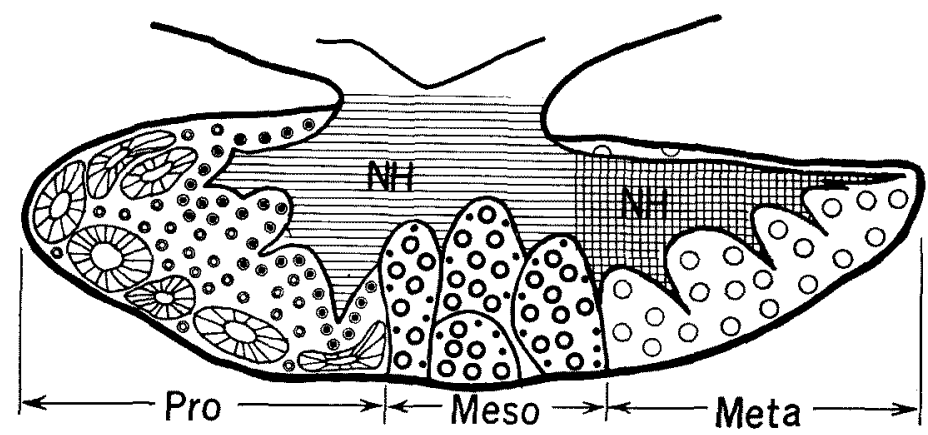

Fig. 1. Diagram of midsagittal section through the pituitary gland of immature male eel. Pro, pro-adenohypophysis; Meso, meso-adenohypophysis; Meta, meta-adenohypophysis; $\mathrm{NH}$, neurohypophysis; prolactin cells; $\odot$, TSH cells; $\odot$, ACTH cells; $\bullet$, GTH cells; $O$, STH cells; $O$, meta-cells; 目, neutrohypophysis including A-F positive material; 团, neutrohpophysis including great amount of $\mathrm{A}-\mathrm{F}$ positive material.

前腺性下垂体は生の秋料では白味を带びて和り，組織切片ではこの部分に3 種の腺緗胞が認められる。そ の大部分の細胞は沪胞状酒列し, 酸性色素に染まる洋梨型の細胞(プロラクチン産生細胞)によつて占めら れている。他方, 正中線付近の神経性下垂体に接した部分に MACCONAILL の鉛へマトキシリンに強く染色 される円形状細胞（副腎皮質刺激ホルモン産生細胞）が棚状に並んでいる。またこれらの細胞の間に aniline blue 扰よび A-F に弱く染まる普通门形で小形の細胞（甲状腺刺激ホルモン産生細胞）が見られる。

脳下垂体の中心部を占める中腺性下垂体は養殖ウナギでは前效よび後腺性下垂体とはとんど同じ大きさで ある。この部分は aniline blue によつて强く染色される薄い膜によつて团まれたいくつかの柱状体 (column) から成る。末成熟ウナギの脳下垂体ではこれらの柱状体の大部分は azocarmine Gによって染色される好酸 性細胞（成長ホルチン産生細胞）によつて占められている。さらに上記の柱状体の周边部に極めて小形の細 胞（生殖腺刺激ホルモン産生細胞）が見られる。

脳下垂体の後端部に位置する後腺性下垂体には最も多くの神経性下垂体の分岐が進入しているが，この部 分には少なくとも 2 種の腺細胞の外にここで用いられたどの染色剂にも染色されない小形の細胞（色素媒性 
細胞)が認められる。

\section{淡水飼育時の脱下垂体の各種ホルモン産生細胞}

i) プロラクチン産生細胞 (LTH 細胞)：この細胞は前腺性下垂体の大部分を占め，azan 染色では azocarmine G, A-F 染色では light green など酸珄色素に染まる (Fig. 2)。しかしウナギのプロラクチン細 胞のこれら酸性色素に対する染色性はメダカ91 や溯上期のサケ101と比較するとかなり弱い。普通この細胞は 洋梨型を呈し，それらが集つて沪胞を形成するが，沪胞の中心部にある腔にしばしば aniline blue お上び A-F 陽性のコロイドがみられる。細胞質内に多数瑟められる分泌顆粒は円形もしくは棈円形で 200-300 $\mathrm{m} \mu$ の大きさを示し電子密度は高く, 一般には腔とは反対側の核の周辺部に多い。粗面小胞体忙く発達し, 時 にはこれらが同心円状に配列することがある (Fig. 8)。ゴルジ体もよく発達しておっりゴルジ落の内部には しばしば小さな顆粒状の物質が蓄積しているのが認められる。腔を取囲も細胞は閉鎖小帯 (tight junction) と接着板 (desmosome) とで互いに結合され，腔側の一端に短い䄉毛と 9+2の典型的な瀻維束を有する緎 毛が認められる。

ii）副竪皮質刺激ホルモン産生細胞（ACTH 細胞）：本細胞は前腺性下垂体の正中線付近の神経性下垂 体に接する部分に普通 2-3 列に並び棚状の層を作つて存在する。この細胞は MACCONALIL の鉛へマトキ シリンで非常に濃い青色に染まる (Fig. 3) のみでなく light green p azocarmine Gなどでもよく染色さ れる。分泌顆粒法普通円形であり 150-250 $\mathrm{m} \mu$ の大きさ示し, 電子密度は一定していない。この細胞の近 くにある結締組織腔 (connective tissue space) は略質瀻維で充たされている。

iii) 甲状腺刺激ホルモン産生細胞 (TSH 細胞)：ウナギでは TSH 細胞は前腺性下垂体の LTH 細胞 と ACTH 細胞との間に存在するが，その数は他の細胞に比し少ない(Fig. 2)。細胞は普通円形で中心部に 丸い核を有する。細胞質は aniline blue などの塩基性色素に弱く染まり，A-F 染色に対しても弱い陽性反 応を示す。この研究では残念ながら淡水中のウナギにお゙汓る本細胞の微細構造を観察することができなかっ た。

iv) 成長ホルモン産生細胞（STH 細胞）：この細胞怯荃殖ウナギでは中腺性下垂体に存在する柱状体 の大部分を占める (Fig. 4)。azan 染色では azocarmine G K, A-F 染色では light green で染色される。 普通円形もしくは棈円形で核は細胞の中央にみられる。電䫓観察では細胞質に円形るしくは棈円形の電子密 度の高い分泌顆粒が多く含まれる(Fig. 10)。粗面小胞体はやや拻張しており，細胞質仁広く分布する。さ らによく発達したゴルジ体も観察されしばしば分泌顆粒の産生像が認められる。糸粒体は中程度に発達して おり, 内部に 2,3 の糸粒体内顆粒が存在する。

v) 生殖腺刺激ホルモン産生細胞 (GTH 細胞)：中腺性下垂体に存在寸る今1つの腺緗胞であるGTH 細胞は養殖ウナギでは非常に発達が悪く, aniline blue 飞染色される薄い膜に沿って少数存在する (Fig. 4)。 細胞は小さく塩基性色素により極めて弱く染色される。電顕観察ではこの細胞は結締組織腔に沿って存在し， 細胞質は小形で電子密度のまちまちな $200 \mathrm{~m} \mu$ 程度の分泌顆粒とこれに混じつて大きなるのでは $3 \mu$ にも 達する電子密度の低い大形の顆䊀が認められる(Fig. 10)。系粒体は円形むしくは桿状で㕕く細胞に分布し ている。

vi）後腺性下垂体の細胞： 後腺性下垂体には神経性下垂体の分岐が深く入り込んでいるが，それらは 腺細胞とは aniline blue 溞く染をる薄い膜によつてへだてられている (Fig. 5)。この膜は電顕観察により 2 枚の基底膜ではさまれた带状の結䋨組織であることが確められた（Fig. 9)。後腺性下垂体の腺細胞は MACCONAILL の鉛へマトキシンで染色すると同染色に陽性の細胞と陰性の細胞の 2 種が認められる。前者 は aniline blue 好性の膜に囲まれた柱状体の周辺部に多く, 後者はむしろ柱状体の中心部に多い。電顕観察 から一応 2 種類の細胞型が区別された (Fig. 9)。第一型の細胞では電子密度の一定しない多くの 150-250 $\mathrm{m} \mu$ の分泌顆粒によつて占められて和り，粗面小胞体，ゴルジ体などの細胞内小器官は比較的少ない。第 2 型は 粗面小胞体，ゴルジ体などがよく発達しているが，分泌顆粒が極めて少ない細胞である。このように腺細胞 を一応 2 種類に分類したが，この中間型のるのるあり両者の区別は確然としていない。また電顕で分類され 
た細胞が光顕で分類されたどの細胞型に対応するかこの研究では明らかにできなかつた。

海水移行時の脳下垂体の各種木ルモン産生細胞について 海水移行に上り変化の認められる細胞は LTH 細胞, TSH 細胞拈よび後腺性下垂体で, ACTH 細胞, STH 細胞扰よび GTH 細胞には柱とんど变 化が認められない。

LTH 細胞は 1/3，1/2 海水で飼育されたウナギでは淡水中のそれとほとんど差異がなからたが，3/4 海水 に一週間飼育したものでは明暸な差が認められた。すなわち, 個かの LTH 細胞惊小さくなり，また酸性色 素に対する染色性も弱くなつた。そして全海水に移行して6週間を経たものではこの相違は一層明睹となつ た。個々の LTH 細胞の大きさが減ずる結果, 沪胞腔が大きくなり (Fig. 6), また細胞は円形となる。細胞 質は酸性色素にほとんど染色されない。電頭による観察でも分泌顆粒は小さくなり，数も減ずる。細胞内小 器官の発達も極めて悪くなる (Fig. 11)。

TSH 細胞は淡水中では塩基性色素にあまり染らず，他の細胞型との区別はかなり困難であつたが，海水 に移行した魚では移行後徐々に大きさを增し，上記架色剂に対する親和性白增大し，全海水に6週間飼育さ れたものでは他の種類の細胞との区別は容易となつた (Fig. 7)。エポンに包埋し, RICHARDSON 5のち法で 染色された切片で細胞内に aniline blue で濃染される 150-250 $\mathrm{m} \mu$ の大きな顆粒が観察される。電顕に 上る観察でも細胞質中に多くの電子密度の高い大形の分泌顆粒が認められた。

後腺性下垂体は海水移行後徐々に柱状体周辺部の細胞方円柱状に配列される上らになり，6週間海水に飼 育したものではこの細胞は RICHARDSON らの方法では染色されなくなる。電頙観察の結果でるこれらの細 胞には分泌顆粒が認められない (Fig. 12)。細胞質には少数の采粒体，少量の粗面小胞体などが見られるが， ゴルジ体は汪とんど認められない。種々の形のラインゾーム, 䋊維状構造も認められた。この特徴ある細胞 は淡水中の魚で認められたどの細胞から由来されたかは不明である。

海水移行と同時にシナホリンを投与した後の脳下垂体の変化＼cjkstart海水移行と同時にシナホリンを投与した 群では海水䔟行のみの群と比較して，LTH 細胞，ACTH 細胞, 後腺性下垂体などの細胞にはほとんど变化 が認められないが，TSH 紐胞，STH 細胞，GTH 細胞には特徵ある変化が観察された。

海水移行と同時にシナホリンを投与した群の TSH 細胞は海水移行時に認められたよらな塩基性色素に対 する強い親和性は認められず，淡水中で飼育されていた魚のTSH 細胞と極めてょく似ていた。

$\mathrm{STH}$ 紐胞はシナホりン投与の回数の增加につれて，大きさ，数，染色性を減し，6回投与して成熟した 個体では GTH 細胞の間にごくわずか認められる上うになる。電顕による観察でもこの細胞は投与後に徐ヶ に分泌顆粒の数が減じ，大きさ 200-300 $\mathrm{m} \mu$ となる。それと同時に細胞内小器官の発達も悪くなり, 新 たな分泌顆粒の形成はほとんど認められない。

STH 細胞の不活性化々は全く対照的に GTH 細胞はこの処理に上り急速に活性化する。シナホリンを 2-3 回投与すると GTH 細胞は徐々に数, 大きさを增し, 投与 6 回目頃には中腺性下垂体の大部分を占め るようになると共に前腺性下垂体にる認められるようになる。そして中腺性下垂体はきわめて大形となる。

電影による観察でも細胞は明らかに大きさを增すと共に，細胞筫中の両種の分泌顆粒は大きさ拉よび数の 增大が認められる（Fig. 13）。むた㧓張した粗面小胞体が細胞質全体に広く分布し，ゴルジ野む大きくなり， そこにしばしば分泌顆粒の産生像が認められる。

\section{考察}

日本産ウナギの腷下垂体に関する形態学的研究は極めて少なく，ホルモン産生細胞の全般について詳紐に 記述した報告はない。この研究で得られた日本産養殖ウナギの脳下垂体の各種ホルモン産生細胞の光顕的特 徵は多くの点でョーロッパ産ウナギのそれ”と類似てている。さらに電顕による観察でもヨーロッパ産ウナ ギで得られた結果11-131 と今回の観察結果とはほとんどの細胞でよく似ていた。しかし GTH 細胞に関して はョーロッパウナギでは KNOWLES と VOLLRATH ${ }^{12)}$ は円形の約 $1,900 \AA の$ vesicle 老持つ第一型と電子密 度の低い $1,300 \AA$ の小さな vesicle を持つ第二型の 2 つの释類と分けている。魚類の GTH 細胞を 2 種類 
に分けているものは他に Zoarces viviparus に関する ÖZTAN ${ }^{14}$, Carassius auratus についての LEATHERLAND $^{151}$ の報告がある。しかし，それらの報告はいずれも実験的根拋がそしい。日本産ウナギについての本 研究では未成熟魚扣よび成熟魚で一種類の GTH 絸胞しか認めるこよができなかつた。同様に一種類の GTH 紐胞しか認められない種類としては Carassius auratus ${ }^{16)}$, Oncorhynchus keta ${ }^{17)}$, Oncorhynchus nerka ${ }^{18}$, Gillichthys mirabilis ${ }^{191}$, Gasterosteus aculeatus ${ }^{201}$, Cymatogaster aggregata ${ }^{211}$ な゙があげられる。 このように現在のところ硬骨魚類の脳下垂体の GTH 細胞に関しては一致した見解が得られて括らず，今後 の研究が期待される。

淡水中ではウナギの LTH 細胞は大きく，多くの大形の分泌顆粒およびよく発達した粗面小胞体，ゴルジ 体などを有するのに，海水移行ではその細胞は小形となり，分泌顆粒も大きさおよび数を減じ，立た細胞内 小器官の発達も悪くなる。これらの結果はウナギおよび他の数種の硬骨魚で知られているよらに 稩胞から分泌されるホルモンは魚が淡水で生存するのに重要な役割を演ずることを示している。しかしウナ ギは Carassius auratus ${ }^{221}$ や Heteropneutes fossilis ${ }^{231}$ などと同様に絪下垂体摘出後でも淡水中で長く生存 できるこが知られている24!。をれゆえ，ウナギの淡水適広には脳下垂体から分泌されるホルモンばかりで なく，他の要因も関係しているものと推察される。

ACTH 細胞はこの研究では海水移行によつて大きな形態变化を示さなかった。硬骨魚に扎いてはACTHcortisol 系は海水適応に関係あることが知られている25,26)。HANKE その他271 はョーロッパ座ウナギを種々 の塩分濃度の水で飼育し，淡水から海水に直接移行して4週間飡育したすので ACTH 細胞の活性が最も高

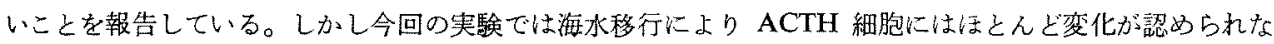
かつた。本実験ではウナギを稀积海水中で馿致してから順次純海水に移行した。それゆえこのような実験 条件のちがいが両者の結果に反映したのではないかと思われる。

TSH 細胞は淡水中では䍀基性色素に対する染色性が弱いが，海水移行後には染色性の増加を示した。 OLIVEREAU ${ }^{281}$ も同様な結果を報告し，これは海水中のヨードの高濃度が脳下垂体に影響し，TSH の分泌を 抑え，その結果 TSH が細胞中に蓄積されたためであるらと述べている。一力，今回の研究で海水移行と共 にシナホリンを投与したものでは，上記のよらなTSH 細胞の染色性の高まりは観察されなかつたしまた OLIVEREAU ${ }^{29 !}$ は TSHを投与することにより雄ウナギを成熟させている。これらの事麦は魚の生殖の㮏 TSH とGTH の間に密接な関係があることを暗示している。

後腺性脳下金体の細胞は海水移行によつて明膫な変化を示す。すなかち，細胞配列に变化が起こりまた分 泌顆粒を欠く特異な細胞が出現する。

これ⿱での研究報告から，今回観察された鉛へマトキシリンに染をる細胞はMSH 分泌細胞の可能性が高 い1,2)。しかし鉛へマトキシリンに院性で時にPAS 反忘に陽性の他の緗胞については現在のとこるその作用 は明らかでない。OLIVEREAU ${ }^{5}$ はョーロッパ圱ウナギと日本産ウナギの後腺性下垂体のPAS 陽性細胞の比 較を行ない，兩者の活性の差，産地間の水質の相湋から，PAS 陽性細胞はカルシウム代謝に何らかの関係 を有するであるらと推察している。本研究の結果も後腺珄下垂体の細胞が滲透王淍節に何らかの役割孝演ず ることを暗示している。

未熟な雄ウナギを海水移行と其にシナホリンを投与することにより，排精に溥くことがでさるが61この間 脳下垂体の GTH 細胞, STH 細胞に大きな変化のみられることが今回の研究で明らかとなつた。すなから 未熟な魚では中腺性下垂体の大部分は STH 細胞で占められるが，成熟したものでは，STH 細胞は極めて 少なくなり，代つて GTH 細胞が顕著に增大する。OLIVEREAU と HERLANT ${ }^{301}$ は雄ウナギ, OLIVEREAU 311 は雌ウナギにホルモンを投与して，これらの催熟に成功しているが，その際起こるGTH緗胞の変化を調べ， 今回の観察と区としど同様な結果を得ている。しかし彼女らはこのような変化の起こる機構については説明 していない。今回の実験でみられたシナホリン投与後に起る GTH 細胞の微細構造の特徽は金魚の生殖腺摘 出啳の GTH 細胞 ${ }^{16}$ 抢よび洋上中のサケの活性化された GTH 細胞 ${ }^{171}$ と形態が極めてょく似ている。このこ とから前報6)で報告された精巣の発垟は，投与したシナホリンが直接精巣に慟いて成熟を四進すると共に， 
さらに視床下部一脳下垂体系に影算し，GTH 細胞の活性化をもたらし，その結果分泌される内生的な GTH も精巣の発達に関与するものと思われる。この問題はさらに詳細な笑験を行ない倹討する予定である。

\section{要䄪}

日本産䖯殖雄ウナギの脳下垂体の一般形態上海水移行およびシナホリン投与後にみられる腺性下垂体の細 胞学的変化を調べ次の結果を得た。

1. ウナギの脳下垂体は前腺性下垂体，中腺性下垂体，後腺性下垂体拉よび神経性下垂体に分けられる。 前腺性下垂体には LTH 細胞, ACTH 細胞, TSH 細胞がみられ，中腺性下垂体には STH 細胞と GTH 細胞とが認められる。さらに後腺性下垂体には少なくとも2 種の腺細胞が区別された。この外に色素嫌性細 胞が腺性下垂体全体に颜められた。

2. 淡水中の未熟のウナ゙ギでは LTH 細胞が高い活性を示した。この時期の中腺性下垂体は小さく，その 大部分は STH 細胞により占められ GTH 細胞は末発達で柱状体の周辺部にごく少数存在する。

3. 海水移行により LTH 細胞は活性を失うが，TSH 細胞は染色性を增す。後腺性下垂体には淡水中の ものではみられなからて特異な細胞が出現する。その他の細胞には大きな变化は認められない。

4. 海水移行と同時にシナホリンを投与した群では中腺性下垂体に極めて顕著な变化が起こる。投与回数 が堌すと共に GTH 細胞は数，大きさおよび染色性を增し，成政した個体では中腺性下金体の大部分を占め ると共に中腺性下垂体の肥大もたらす。これに反し，STH 絧胞は数，大きさ，染色性を減ずる。

\section{文献}

1) J. N. Ball and B. I. Baker: In "Fish Physiology" (W. S. Hoar and D. J. Randall, eds.), Vol. II, 1-100, Academic Press, New York and London (1969).

2) M. SAGE and H. A. BERN: International Review of Cytology, 31, 339-376 (1971).

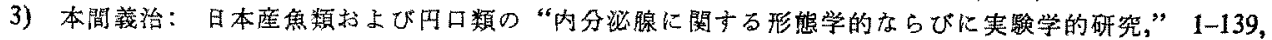
文久堂, 新潟 (1960).

4) M. OGURI: 本誌, 37, 577-584 (1971).

5) M. Olivereau: Z. Zellforsch. Mikrosk. Anat., 99, 389-410 (1969).

6) 山本喜一郎, 広并修, 平野忠, 森岡孝朗: 本誌 38, 1083-1090 (1972).

7) M. A. MacConaill: J. Anat., 81, 371-372 (1947).

8) K. C. Richardson, L. Jarett, and E. H. Finke: Stain Technol., 35, 313-323 (1961).

9) Y. NaGaHAMA and K. Yamamoto: 本苔, 37, 691-698 (1971).

10) Y. Nagahama and K. Yamamoto: Bull. Fac. Fish., Hokkaido Univ., 21, 169-177 (1971).

11) F. Knowles and L. Vollrath: Phil. Trans. Roy. Soc. London, B 250, 311-327 (1966).

12) F. KNOWLES and L. VolLRATH: 同誌, B 250, 329-342 (1966).

13) F. KNowles and L. Vollrath: Z. Zellforsch. Mikrosk. Anat., 75, 317-327 (1966).

14) N. ÖZTAN：闹誌, 69, 699-718 (1966),

15) J. F. LEATHERLAND: Can. J. Zool, 50, 835-844 (1972).

16) Y. Nagahama and K. Yamamoto: Gunma Symposia on Endocrinology, 6, 39-55 (1969).

17) 長浜嘉孝, 山本喜一郎: 北海道大学水座学部研究䁷報, 20, 293-302 (1970).

18) Y. Nagahama and K. Yamamoto: Bull. Fac. Fish., Hokkaido Univ., 20, 159-168 (1969).

19) D. Zambrano: Gen. Comp. Endocrinol., 17, 164-182 (1971).

20) J. F. Leatherland: Z. Zellforsch. Mikrosk. Anat., 104, 318-336 (1970).

21) J. F. LEATHERLAND: 同誌, 98, 122-134 (1969).

22) W. Chavin: J. Exp. Zool., 133, 1-45 (1956).

23) B. I. SUndararaj and S. S. W. Goswam: 同誌, 168, 85-104 (1968).

24) M. Fontaine, O. Callamand, and M. Olivereau: C. R. Acad. Sci., 232, 2477-2479 (1949).

25) 小梁幹郎: 本誌, 36, 638-650 (1970).

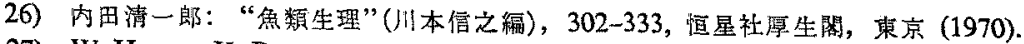

27) W. Hanke, K. Bergerhoff, and D. K. O. Chan: Gen. Comp. Endocrinol., suppl., 3, 331-341 (1969). 
28) M. Olivereau and J. N. Ball: Mem. Soc. Endocrinol., 18, 57-85 (1970).

29) M. Olivereau: C. R. Acad. Sci., 252, 3660-3662 (1961).

30) M. Olivereau and M. Herlant: C. R. Seanc. Soc. Biol., 154, 706-709 (1960).

31) M. Olivereau: Z. Zellforsch. Mikrosk. Anat., 80, 286-306 (1967).

\section{Explanation of Plate I}

Fig. 2. Pro-adenohypophysis of intact fresh-water eel. Prolactin cells (P) are arranged in a follicular form. Around the follicles, a small number of TSH-cells $(T)$ are found. azan. $\times 500$.

Fig. 3. Pro-adenohypophysis of intact fresh-water eel. ACTH cells (A) which form a palisadelike layer bordering the neurohypophysis $(\mathrm{NH})$ are strongly stained by lead hematoxylin. In contrast, prolactin cells $(P)$ are negative to lead hematoxylin. lead hematoxylin. $\times 500$.

Fig. 4. Meso-adenohypophysis of intact fresh-water eel. Most of the lobe is occupied by numerous STH cells (S). A small number of GTH cells $(G)$ are located at the peripheral region of the cell columns. azan. $\times 500$.

Fig. 5. Meta-adenohypophysis of intact fresh-water eel. NH, neurohypophysis. azan. $\times 500$.

Fig. 6. Pro-adenohypophysis of the eel six weeks after being transferred from fresh-water to sea water. Prolactin cells $(\mathrm{P})$ are quite reduced in size and staining affinity for azocarmine G. azan. $\times 500$.

Fig. 7. Pro-adenohypophysis of the eel six weeks after being transferred from fresh-water to sea water. TSH cells (T) are strongly stained by aldehyde fuchsin. P, prolactin cells. A-F. $\times 500$.

\section{Explanation of Plate II}

Fig. 8. Prolactin cells of intact fresh-water eel. The cells contain electron-dense secretory granules and well-developed rough endoplasmic reticulum (ER). $\times 18,000$.

Fig. 9. A portion of meta-adenohypophysis of intact fresh-water eel. One cell type (A) has well-developed rough endoplasmic reticulum and Golgi apparatus. The other type (B) contains many secretory granules. $\times 8,000$.

Fig. 10. A portion of meso-adenohypophysis of immature fresh-water eel. STH cells (S) have many electron-dense secretory granules. GTH cells $(G)$ contain many mitochondria and a small number of low electron-dense secretory granules. $\times 12,000$.

\section{Explanation of Plate III}

Fig. 11. A portion of pro-adenohypophysis of the eel six weeks after being transferred from fresh-water to sea water. Prolactin cells (P) are reduced in size and their secretory granules are markedly decreased in number and size. TSH cells (T) include a number of electrondense large secretory granules. $\times 15,000$.

Fig. 12. A meta-adenohypophysial cell observed in the pituitary gland of the eel six weeks after being transferred from fresh-water to sea water. $\times 22,000$.

Fig. 13. Well-developed GTH cells $(G)$ of sea water male eel brought to maturity by the injection of Synahorin. g, Golgi apparatus. $\times 15,000$.

Fig. 14. STH cells (S) of sea water male eel brought to maturity by the injection of Synahorin. Their secretory granules are small in size and number. $\times 12,000$. 
Plate I
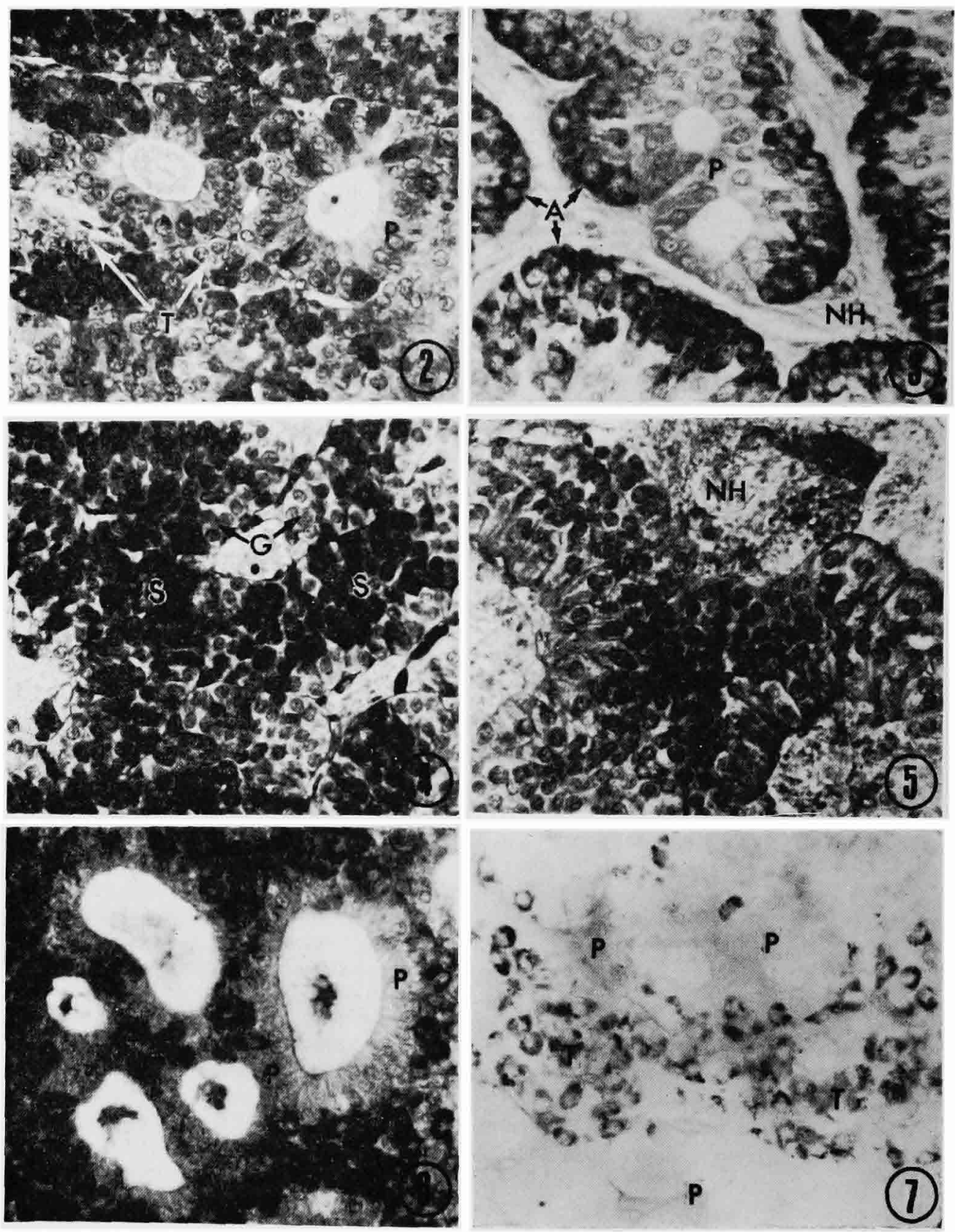
Plate II

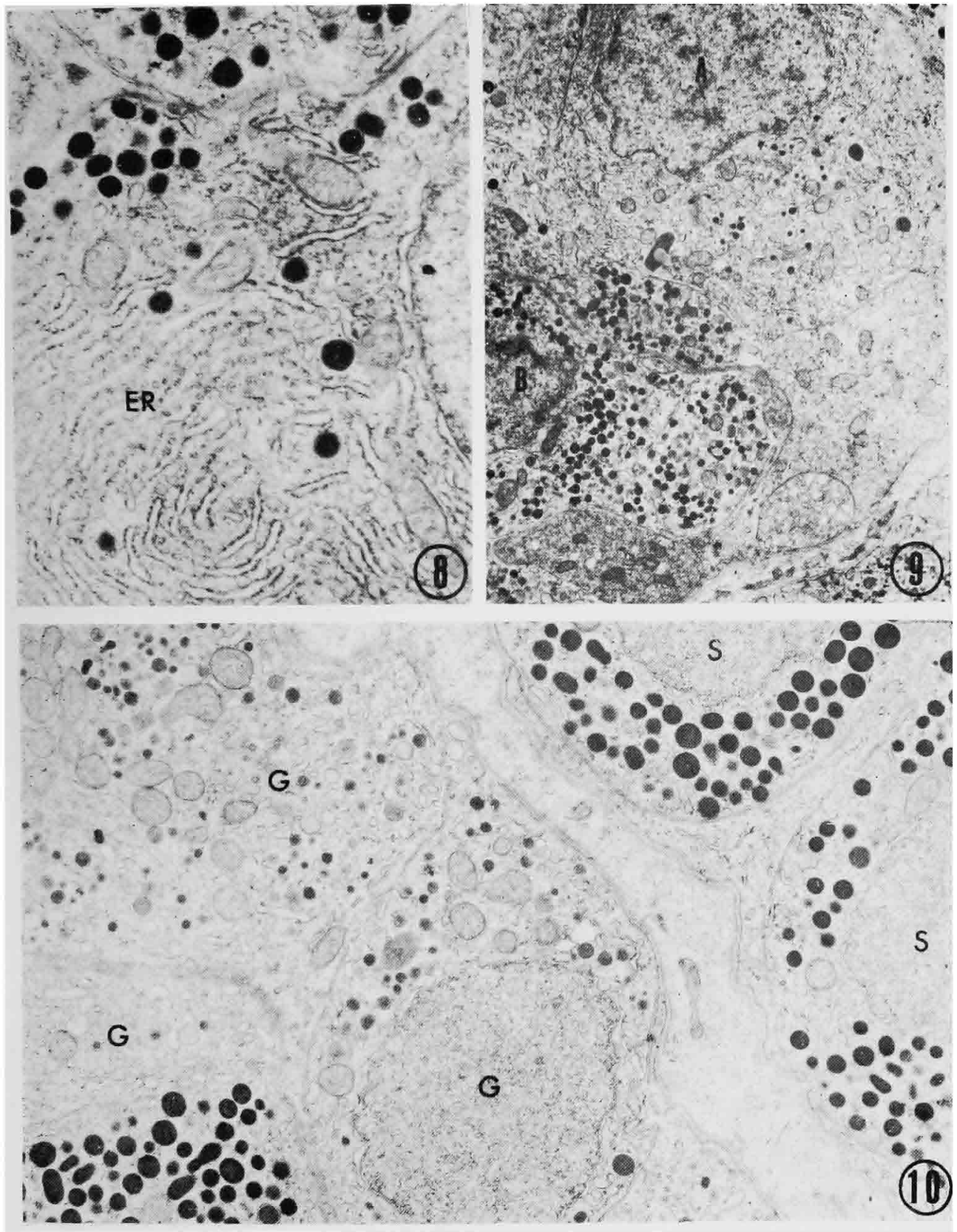


Plate III
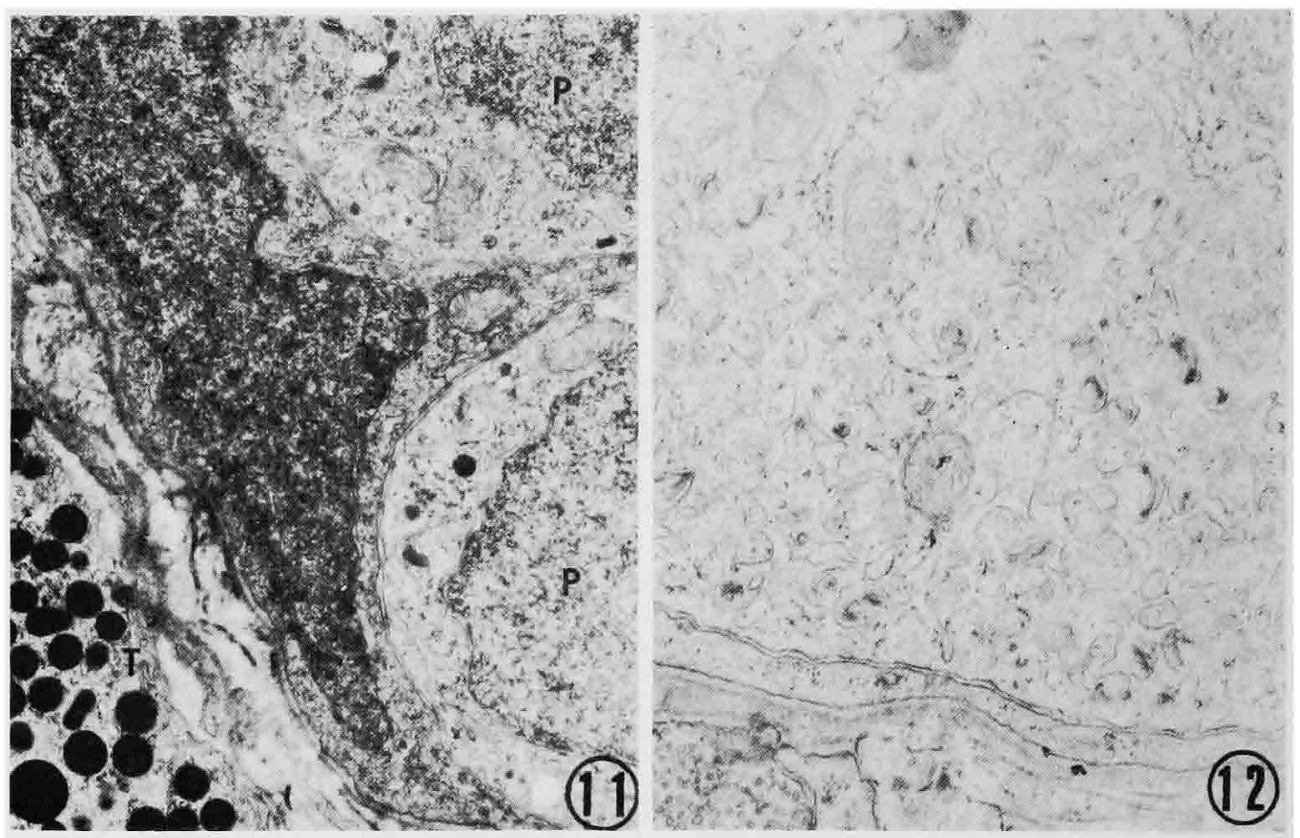

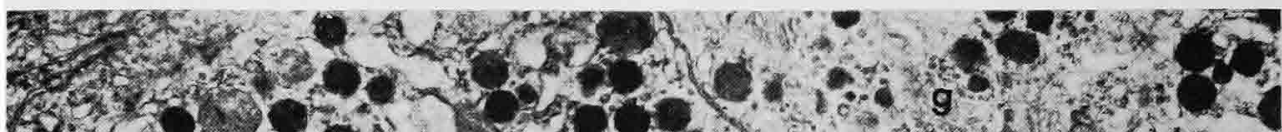
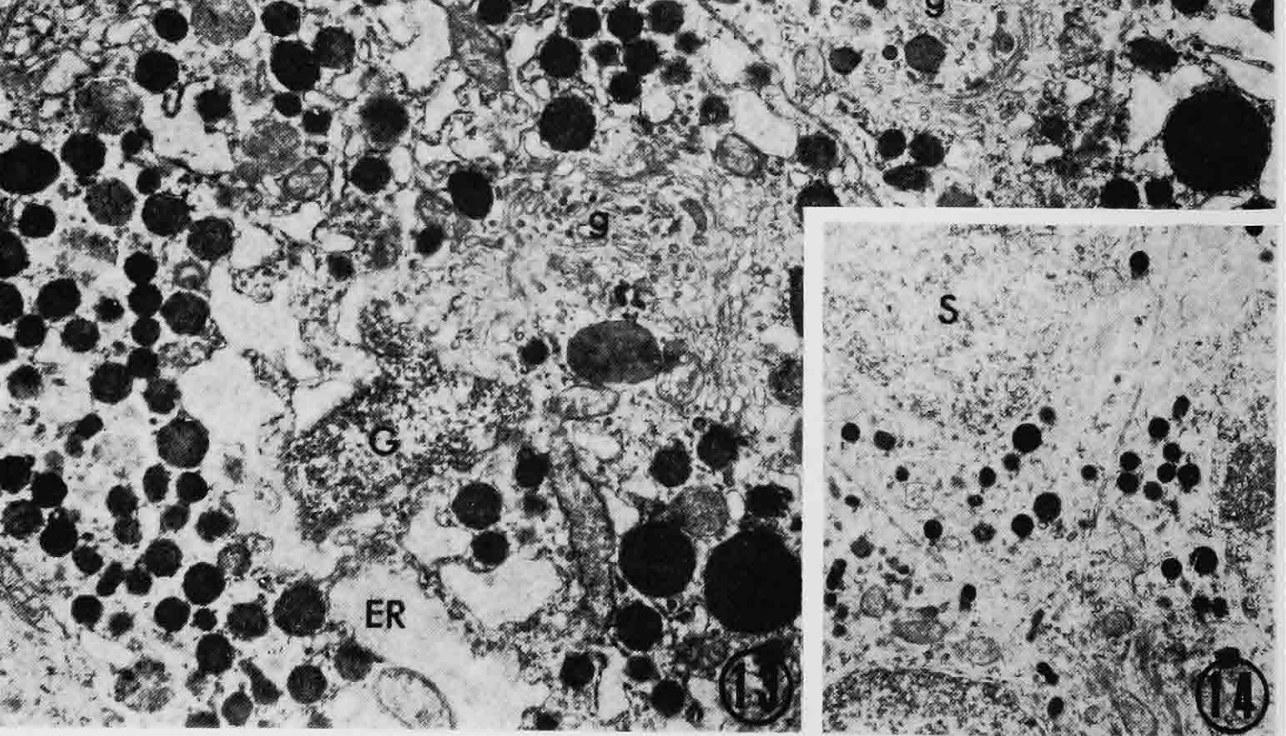